\begin{tabular}{|c|c|c|c|}
\hline Article Info & REVIEW ARTICLE & DERLEME MAKALESİ & \\
\hline Title of Article & \multicolumn{2}{|c|}{$\begin{array}{c}\text { An Essay on the Human \& Nature } \\
\text { Relations: The Ecologist Approaches in the } \\
1960 \text { s and } 1970 s\end{array}$} & \\
\hline $\begin{array}{l}\text { Corresponding } \\
\text { Author }\end{array}$ & \multicolumn{2}{|c|}{$\begin{array}{l}\text { Hasan Basri KARTAL } \\
\text { Nottingham Üniversitesi, Mimarlık ve Yapılı Çevre Bölümü, Doktora Öğrencisi, } \\
\text { hbasrik@gmail.com }\end{array}$} & \\
\hline $\begin{array}{l}\text { Received Date } \\
\text { Accepted Date }\end{array}$ & \multicolumn{2}{|l|}{$\begin{array}{l}15.09 .2020 \\
20.11 .2020\end{array}$} & \\
\hline Author / Authors & $\begin{array}{l}\text { Hasan Basri KARTAL } \\
\text { Asiye Nisa KARTAL }\end{array}$ & $\begin{array}{l}\text { ORCID: 0000-0003-1586-9596 } \\
\text { ORCID: 0000-0002-6805-6778 }\end{array}$ & \\
\hline How to Cite & \multicolumn{2}{|c|}{$\begin{array}{l}\text { KARTAL,H.B. and KARTAL, A.N. (2020). İnsan ve Doğa İlişkisi Üzerine Bir } \\
\text { Deneme:1960 ve 1970'lerde Çevrecilik Yaklaşımları, Kent Akademisi, Volume, 13, } \\
\text { Issue 4, Pages, -761-770 }\end{array}$} & $\begin{array}{l}\text { Kent Akademisi } \\
\text { Urban Academy }\end{array}$ \\
\hline
\end{tabular}

\title{
İnsan ve Doğa İlişkisi Üzerine Bir Deneme: 1960 ve 1970'lerde Çevrecilik Yaklaşımları
}

ÖZ:

Bu makalenin amacı 20. yüzyılın başlangıcından itibaren 1970'lerin sonuna kadar uzanan süreç içerisinde insan doğa ilişkilerini mesele edinen çevrecilik kuramlarını incelemek, çevre hareketlerini ve bu dönem içinde ortaya çıkmış çeşitli ekolojik yaklaşımların nasıl ilerlediğinin teorik bir analizini yapmaktır. Makale, 20. yüzyılın başlangıcından itibaren 1960'lara kadar uzanan süreç içerisinde insan doğa ilişkilerinin felsefi olarak nasıl ilerlediğinin tartışmasını yaparak başlar ve 1960 ve 1970 arasındaki dönemde, çevrecilik hareketlerine, insan çevre anlayışlarının bu dönem içindeki gelişimine, insanın çevre ile zihinsel ve edimsel ilişkisinin boyutlarının değişimine odaklanır. Makale, 1960'ların sonu ve 1970'lerin başındaki sivil haklar, ifade özgürlüğü ve kadın, barış ve çevre/ekoloji hareketlerinin, kentsel kuram ve yaklaşımlarda köklü dönüşümün göstergeleri olduğu sonucuna varır.

ANAHTAR KELİMELER: İnsan-Doğa İlişkisi, Çevre, 1960 ve 70lerde Çevrecilik Hareketleri, Ekoloji

\section{ABSTRACT:}

This article aims to discuss the human and nature relations in the period from the beginning of the 20th century to the end of the 1970s and make a theoretical analysis on the ecological theories, environmental movements and ecological approaches. The article begins by revealing the progression of human-environment relations in the philosophy from the beginning of the 20th century to the 1960s. Then, it focuses on the ecological movements, development of humanenvironmental conceptions, and changes in the dimensions of the intellectual and pragmatic links of the man with the environment in the period between the 1960sand 1970s. The article concludes with the discussion with the idea that the civil rights, freedom of expression, and the women's movements, peace and environment/ecology movements have been the fundamental indicators of the transformation in the concepts of environment theories and attitudes in the 1960 s and 1970s.

\footnotetext{
${ }^{1}$ Nottingham Üniversitesi, Mimarlık ve Yapılı Çevre Bölümü, İngiltere, öğrenci

${ }^{2}$ Nottingham Üniversitesi, Mimarlık ve Yapılı Çevre Bölümü, İngiltere, öğrenci
} 
KEYWORDS: Human-Nature Relations, Environment, Environmental Movements in the 1960s and 1970s, Ecology

\section{GíRiș}

20. yüzyıl çevre hareketleri açısından çok hareketli bir yüzyıl olmuş, özellikle 20. yüzyılın ikinci yarısından itibaren çok farklı sayıda çevreci yaklaşım ve çevre felsefesi tutumu ortaya konmuştur. Yüzyıl'ın ilk yarısında, daha çok 19. yüzyıldan itibaren devam eden doğa koruma anlayışına bağlı romantik tepki olarak nitelendirilebilecek tepkiler görülmüştür. Yüzyılın ikinci yarısından itibaren ise giderek güçlenen ve bilimsel çalışmalarla da desteklenmiş çeşitli ekoloji hareketleri ortaya çıkmış, bu hareketler farklı birçok disiplini de etkilemiştir (Bookchin, 1994). Şüphesiz 20. yüzyll içerisinde çevreci hareketlerin özellikle 1960'lardan itibaren yükselişe geçmesinin kökeninde modernizm idealine duyulan şüphe ve modernizmin acı etkilerinin görülmesi önemli bir rol oynamıştır (Hamlyn, 1987). İki savaş geçiren Batı medeniyeti Aydınlanmacı aklın etkilerini görmüş, bu etkiler bağlamında ilerleme anlayışına olan inancı sarsılmıştır. Bu dönemde, dünya nüfusunun çok hızlı bir biçimde artmaya başlamasıyla çeşitli insan kaynaklı doğa felaketleri yaşanmaya başlamıştır. Batı dışı sömürülen toplumların sömürücü toplumlara karşı sesi yükselmeye başlamış, doğayı mekanik ve matematiksel bir model olarak alan Batı toplumunun doğa ile kurduğu ilişki krize girmiş, paradigmatik bir kırılma yaşanmıştır. Bu bağlamda ortaya çıkan yaklaşımlar insan-merkezli ve teknolojimerkezli doğa anlayışlarını ciddi biçimde eleştirilere tabi tutmuştur. Doğanın kaynak olarak ele alınması yadsınmış, doğadaki zorunluluğa tabi yasaların insan özgürlüğüne engel olarak ele alınmasına dayalı gelenek ciddi biçimde sorgulanmıştır (Ünder, 1996).Bu kriz ve kırılmalar eşliğinde ortaya çıkan çevreci yaklaşımlardan bazıları şunlardır; Derin Ekoloji, Ekofeminizm, Marksist Ekoloji, Liberal Ekoloji, Çevre Etiği, Yeni-Malthusçuluk, Hayvan Hakları Etiği, Toprak Etiği, Toplumsal Ekoloji, Chipko Hareketi, Sürdürülebilirlilik ve Pragmatik Ekoloji, Ekozofi T, Holistik Yaklaşım, Bireycilik anlayışı, Ekoaraşizm, Ekofaşizm, Ekoterörizm, Gaia Hipotezi, Toplam Ekosistem Bilimi, NeoEkoloji, Yerleşim Ekolojisi, Uygulamalı Ekoloji (Sosyal Ekoloji/İnsan Ekolojisi), Sosyobiyoloji, Çevre-Davranış Kuramları gibi. Görüldüğü üzere 20. yüzyılın son çeyreği çevrecilik hareketleri açısından çok farklı yaklaşımların izlendiği bir dönem olmuştur (Frodeman \& Foltz, 2004). Gerek 20. yüzyıl içerisinde çok fazla çevre üzerine fikir üretmiş düşünürün olması, gerekse eylem, organizasyon, toplantı gibi çevreci aktivitelerin çok olması nedeniyle; bu dönem için üretilmiş literatür bir makalenin kapsamını aşmaktadır. Bu nedenle bu makalede bu dönem ile ilgili olarak ortaya çıkmış temel akımlara ve bu akımların oluşumuna öncülük etmiş önde gelen düşünürlere değinilecek, çok fazla ayrıntıya girilmeyecek, çevreci yaklaşımlara ek olarak ortaya çıkan felsefi yaklaşımların doğa görüşleri de genel hatları ile ele alınacaktır.

\section{Felsefi arka plan}

20. yüzyıl felsefesinin ilk yarısında etkili olan felsefi yaklaşımları genel olarak Kıta Avrupa'sı ve Anglo-Sakson geleneği olarak ikiye ayırabiliriz. Bu bağlamda Kıta Avrupası felsefesi içerisinde Yapısalcılık, Fenomenolojik Ontoloji, Hermenötik, Eleştirel Felsefe (Frankfurt Okulu) ve Viyana Çevresi (Mantıksal Pozitivizm) yer alırken; Anglo Sakson ve Amerikan düşüncesi içerisinde Analitik Felsefe, Pragmatizm ve Eleştirel Bilim Felsefelerini saymak mümkündür. Çevreci bir felsefe olarak çıkmamış ancak doğa ve ekoloji konusunda çeşitli yaklaşımlar geliştirmiş bu akımlara kısaca değindikten sonra felsefesinin merkezine doğayı ya da ekolojik kaygıları yerleştiren felsefi tutumlara değinilecektir. Bu bağlamda 20. yüzyılın başında ortaya çıkmış ve dilbilimden mimarlığa kadar birçok alanı etkilemiş Yapısalcılık düşüncesi genel olarak ele alınan problemin, sorunun, konunun vs. bir yapı olarak ele alınmasını, tarihsel bağlamından kopartılarak parçaları ile olan ilişkisi bağlamında incelenmesi gerektiğinin altını çizer. Bu yaklaşım temel olarak modernizmin özneyi merkeze alan konumuna karşı öznenin yapı içerisindeki diğer unsurlar ile özdeş ve ilişkili ele alınması yolunu tercih eder. Genelleyecek olursak, yapısalcılık düşüncesi, doğayı kendi içerisinde bir bütün olarak ele alır, ekosistem anlayışına katkıda bulunur, doğa kültür zıtlığına değinir ve doğayı da dilbilimsel kodlara benzer bir sistem gibi görmeye çalışarak inceler. Epistemolojik kökenli ortaya çıkan ve doğada bulunan varlıkların özünün bilgisine ulaşmayı hedefleyen Transandantal Fenomenolojiye karşı, insanın ontik ve ontolojik yapısının önemine vurgu yapana Fenomenolojik Ontoloji ya da Varoluşçu Fenomenoloji, varoluşsal farkındalığa katkıda bulunan bir yapı olarak doğayı konumlandırmıştır. Özne-nesne düalizmini yıkma yolunu seçmiş, doğayı insan varoluşunun bir uzantısı olarak ele almış, teknoloji merkezli yaklaşımı eleştirmiștir, doğaya içsel değerlerin farkındalığına vararak yönelinmesi gerektiğini savlamıştır (Gallagher, 2012). İnsan varlığının fenomenolojik ontoloji bağlamında nasıl anlamlandırılacağı problemine odaklanan Hermeneutik, doğayı da materyalist bir indirgemecilikle açıklayan natüralist yaklaşımları eleştirmiş̧, çevrenin insan varlığına olan katkısının nasıl anlamlandırılabileceği problemine odaklanarak çevresel bir hermeneutik yaklaşım geliştirmiş̧ir. Bu düşünme sekli, çevre merkezli olarak bireyi anlama yolunu seçmiş, doğa sayesinde yaşanın tecrübenin varoluşsal önemini vurgulamıştır. 
Aydınlanma ve modernizm eleştirileri bağlamında Marksist bakıș açısıyla sosyolojik analizler yapan Frankfurt Okulu düşünürleri Modernizmin bilim ve teknoloji anlayışını ve Ortodoks Marksizm'ini ciddi şekilde eleştirmişler, Aydınlanma düşüncesinin doğaya hâkim olma düşüncesine meşruluk kazandıran yapısını ciddi biçimde sorgulamışlardır.

$\mathrm{Bu}$ anlayışın insanı tek boyutlu bir yapıya indirgediğini savlamışlar, teknolojinin giderek insan ve doğa üzerinde hakim olacağına dair öngörüde bulunmuşlardır. Doğadan kopuşun kökeninde doğanın nitel ve nicel değerlere indirgenişini sorumlu tutan Frankfurt Okulu düşünürleri, doğanın kapalı bir yapı olarak ele almak suretiyle, doğanın ve doğa ile etkileşime girmesi bağlamında insanın özgürlüğünün kısıtladığını ileri sürmüşlerdir (West, 1998). Viyana Okulu (Mantıksal Pozitivizm), Kıta Avrupası felsefelerinin yaklaşımlardan daha farklı bir doğa anlayışını benimsemiş, Anglo-Sakson düşüncesine daha yakın bir yolu benimsemiştir. Viyana Okulu düşünürleri doğadaki spekülatif ya da metafizik olarak gördükleri ilkelerin doğadan temizlenmesinin yolunu aramışlardır, diğer bir deyişle, doğayı olgulara indirgeyip olgular arası ilişkileri matematik ve mantık yoluyla doğrulama yolunu seçmişlerdir. Anglo Sakson felsefe geleneğinin hâkim yaklaşımlarından biri olan Analitik Felsefe de Mantıksal Pozitivistlerin yolunu benimsemiş, doğayı salt mantık ilişkileri dahilinde birbiri ile ilişkiye giren bir yapı olarak ele almışlardır. Eleştirel bilim felsefecileri doğa ile ilgili olarak üretilen kuramların insanın önyargılarından, içine doğdukları toplumun ve kültürün değer yargılarından bağımsız olamayacağını ileri sürmüşler, doğayı egemenlik altına alan bilimsel kuramları da eleştirmişlerdir (West, 1998). Amerikan Pragmatistleri doğanın daha uzun süre kaynak olarak kullanılabilmesi için tüketim ilişkilerinin azaltılmasının gerekliliğini vurgulamışlar, Aydınlanma ve Modernizm'in doğaya egemenlik anlayışını eleştirmişlerdir. Bu grup, ekolojik duyarlılığın önemini vurgulamış, nükleer enerji ve yenilebilir çevresel kaynaklara öncelik verilmesinin gerekliliğini savlamış ve çevre felaketlerinin kaynağı olarak doğaya aşırı derecede yüklenmenin neden olduğunu ileri sürmüştür (Jackson, \& Jackson, 1996). Felsefi yaklaşımların dışında 20. yüzyılın başında ortaya çıkan Gestalt Psikolojisi de doğanın bütüncül bir bakış açısı ile ele alınması gerekliliğinin altını çizmiştir; bütün, parçaların toplamından daha fazladır anlayışı ile doğaya yönelik analitik yaklaşımları eleştiren bu düşünce, insan psikolojisinin uzantısı olarak gördükleri çevre ile olarak çevre ve davranış kalıbını birlikte incelemişlerdir (Hamlyn, 1987).

20. yüzyılın ilk yarısında ortaya çıkan yaklaşımlar genel olarak Sanayi Devrimi ile kentlere artan göçün, kentleşmenin kötücül etkilerine üzerine kurgulanmıştır. Kırsala dönüş çağrıları, organik çiftlik hareketleri, çevresel ütopyalar 20. yüzyılın ilk yarısına damgasını vurmuştur. I. Dünya Savaşı'nın yıkıcı etkilerinin ardından ekolojik duyarlılık fikirleri yükselişe geçmiş, ancak bu duyarlılıkların eyleme dönüşmeleri İkinci Dünya Savaşı'ndan sonra olmuştur (Jackson \& Jackson, 1996).

\section{20. yüzyıl başından 60'lara}

1900 ile 1910 arasındaki ilk on yıllık dönemde belli başlı şu hareketler gerçekleşir: 1902'de Amerikan botanikçi George Washington Carver doğal tarımın korunması ve toprak kaybının önlenmesini tartışarak 'How to Build Up Worn Out Soils'i yayımlar, 1903'te Theodore Roosevelt Florida'daki Pelikan Adası'nda ulusal kuş koruma yasasını yürürlüğe koyar ve Patagonya'daki 7300 hektarlık alan ilk ulusal park olarak tasarlanır.1905'te hava kirliliğini ifade eden 'smog' terimi kötüleşen hava koşullarındaki endişeleri ifade etmek için Londra toplantısında Henry Antoine Des Voeux tarafindan ilk kez kullanılır, yine aynı yıl Amerika merkezli en eski organizasyonlardan biri olarak 'National Audubon Society' John James Audubon'ın adını alarak kurulur.1906'da San Francisco depremi kentin çevresine yayılan şiddetli depremlerin oluşmasına sebep olur, iki yıl sonra ise Amerika'da 'Ulusal Koruma Komisyonu' Roosevelt tarafindan kurulur. Aynı yıl Robert Underwood Johnson tarafindan kaleme alınan ve temiz suyu elde etmenin zorluklarından bahseden makalesi ulusal çapta bu konuda dikkatleri üstüne çeker. İkinci on yıllık süre olan 1910-20 arasında ise şu değişimler yaşanır: 1913'te Amerikan kongresi California 'da su havzası olan Hetch Hetchy vadisinin korunması ve mevcut tahribatın durdurulması adına yeni bir yasayı yürürlüğe koyar ve Hetch Hetchy Vadisindeki baraj yapımı engellenir. Üç yıl sonra 1916'da Amerika çapında ulusal park hizmetleri kurulur ve 1918'de California'daki kızılçam ormanlarını korumak adına yeni bir organizasyon kurulur. Aynı yıl kongre göçmen kuşların güzergâhının korunmasını adına yeni bir hareket yaratır.1919 da Parklar Koruma Derneği faaliyete geçer. Üçüncü on yılda ise, -1920 ile 30 arası dönemde- İzaak Walton Konseyi kurularak doğal kaynakların korunması adına çalışmalar yapılır.1924'te tekstil işçisi Nellie Kershaw'in yaygın olarak kullanılan asbeste maruz kalıp hayatını kaybetmesi üzerine asbestin zararlı etkileri farkedilmeye başlanır. Ardından, 1927'deki Büyük Missisipi taşkını önemli zararlara sebep olur. 1930'lardan itibaren, geniş çaplı toprak bozulması sebebiyle ABD ve Kanada'da kum firtınaları ve kuraklık ortaya çıkar. 1933'te Almanya'da hayvan haklarının ortaya çıkışı Aldo Leopold'un 'Game Management' yayınlaması ile eş zamanlıdır.1934 itibariyle Amerika'da Ulusal Vahşi Yaşam Federasyonu Kır Toplumu, Balık ve Vahşi Yaşam'ın korunması adına çeşitli koordinasyon birimleri oluşturulur. 1939'da Paul 
Hermann Müller tarafindan DDT icat edilir.1940'lardan sonra 1950'ye kadar olan dönemde ise şu gelişmeler gözlenir:1947'de ulusal çapta kullanılan böcek ve mantar ilaçlarının zararlarının azaltılması adına 'FIFRA' hareketine başlanır.1948'de İsviçre merkezli doğal yaşamı ve kaynakları koruma adına bir organizasyon düzenlenir ve vahşi yaşam savunuları üzerine çeşitli fikirler ortaya atılıp, kararlar alınır.1949 da ise Aldo Leopold'un çevre etiği fikrine göndermeler yapan A Sand County Almanac yayımlanır.1951'de Amerika'da çevre koruma organizyonlarından biri olan ve kötüleşen hava koşullarının stabil kalması adına fikirler üreten WMO kurulur. 1951'deki Doğa Koruma kurulunun ardından, 1954 'te ilk nükleer enerjiden elektrik üretimi gerçekleşir ve 1955 'te hava kirliliği kontrolü hareketine başlanır. 1958 'de havadaki CO2 salınımın ölçülmesi ve global çapta meydana gene atmosfer tahribatı kaynaklı değişimlerin fark edilmesi ile 60ların yoğun çevreci hareketler dönemine girilir (Beck, 1990; Pepper, 1996; Crowe,1999).

\section{1960’lar}

1960'lar ile çeşitli aktivist ve öğrenci hareketleri, Barış hareketleri, Anti-Nükleer hareketler ve Kadın hareketleri belirmiştir. Önceleri sol yelpaze içerisinde yer alan bu hareketler giderek bütün topluma yayılmış, ekolojik çalışmaların artması ile 1960 sonrası yaygınlık kazanan yaklaşımlara ekolojik bir karakter de eklenmiş, bir süre sonra bu hareketlere yönelik ekolojik muhalefetler de ortaya çıkmıştır (Crowe,1999; McLennan, 2004).

Birçok araştırmacı 1962 yılında Rachel Carson’un Silent Spring (Sessiz Bahar) adlı eserini Ekoloji çağının başlangıcı olarak kabul etmektedir. 1960'ta Wallace Stegner tarafindan 'Wilderness Letter'in yayımlaması, vahşi yaşam dayanışma derneklerin yeni bir solukla yeniden kurulmasını sağlar ve su kirliği üzerine ulusal çapta koruma hareketlerine başvurulur. 1961'de WWF'in çeşitli organizasyonlar düzenlemesi doğal çevrenin araştırılması ve korunması adına önemli tartı̧malara sahne olur.1962'den itibaren doğal çevreye verilen tahribatları, özellikle tarım ilaçlarının gelişigüzel kullanımı dolayısıyla meydana gelen su ve toprak örtüsünün bozuluşunu konu edinen bir dizi hareket meydana gelir.1965'te Amerika merkezli temiz su, hava ve zararlı atıklara karşı çevreyi koruma hareketleri düzenlenir.1960'ların sonlarında ise dünyada açıkça gözlenebilen dramatik bir dönüşüm söz konusu olmuştur (Bookchin, 1996a; Bookchin,1996b).

Yirminci yüzyıldaki iki dünya savaşı sonrasında; dünya, hem oluşan yeni sosyal ve kültürel iklimle, hem de hızlanan endüstriyel büyümenin ekseninden çıkardığı çevre kirliliği, ekolojik yıkım ve kaynak sorunlarıyla, ekolojik mücadenin gerçek anlamda toplumsallaşmasına sahne olmuştur (Başkaya, 2004). Örneğin, 'Sessiz Bahar'a giden yolda İkinci Dünya Savaşı'nda kimyasal silah olarak geliştirilen DDT gibi klorlu organik bileşiklerin mucizevî böcek öldürücüler olarak ekonomik gerekçelerle yaygın kullanılması rol oynamıştır. Hem insan sağlığına hem de diğer canlıların varoluşuna kasteden sayısız kimyasal madde sebebiyle, su ve toprak kirliliği çözülmesi güç bir hale gelmesini de eklemiş̧tir. Üstelik bu durum, 19. yüzyıldan beri ciddi bir sorun olan hava kirliliğini de arttırmıştır. 60'ların sonuna doğru iyice hızlanan büyüme, petrol bağımlılığının arttırmıştır. Ardından belirginleşen kaynak sorunu ve hızlı nüfus artışı, insanlığı nasıl bir gelecek beklediği sorusunun daha yüksek sesle sorulmasına yol açmıştır (Des Jardins, 2006; Conyne \& Clack, 1981).

\section{1970'ler}

1970'lerin başında giderek yaygınlaşan ekoloji hareketlerine bilimsel ve eğitsel olarak etki eden ve bu hareketin oluşumuna kaynaklık eden B. Commoner'in Science and Survival'1; P. Ehrlich'in The Population Bomb'u, G. Hardin'in The Tragedy of Commons'u, H. Odum'un Environment, Power and Society'si; kamuoyunun dikkatini ekolojik problemlere çekebilmeleri bağlamında değerli çalışmalardır. Fakat, ekolojik sorunların serimlenmesi ve doğa korumacılık önerilerinin sunulması yerine ekolojik yaklaşım modellerinin ortaya konduğu ikinci kuşak yayınlar bu dönemin en önemli çıktılarıdır, bu yayınlardan bazılarını şu şekilde sıralanabilir. Roma Kulübünün yayınladığı Büyümenin Sınırları Raporu, E. Goldsmith'in Yaşam Şablonu, F. Schumacher'in Yaşam Şablonu. Pepper, bu üç eseri modern çevreciliğin ilkelerinin yayınlandığı ve paradigmatik kırılmayı gerçekleştiren dönüm noktaları olarak ele almıştır. Bu üç yayından ilki temel sorunların doğasını ve boyutlarını yorumlamış, ikincisi bu sorunların aşılması için hangi tip çözümlere ihtiyaç duyulduğunun analizini yapmış, üçüncü kitap ise bu sorunlara yönelik felsefi düzlemde ortaya atılan kuramlar ile uygulamalar arasındaki ilişkileri incelemiştir. Bu yayınların etkisiyle ortaya çıkan uluslararası organizasyonlar ve kongreler modern çevreciliğin ilk adımları olarak ele alınabilir (Greenpeace, Friends of Earth gibi örgütlenmeler) (Bookchin, 1999). Bu dönemin bir neticesi olarak, ekolojik hareket en üst kitleselleşme düzeyine ulaşmış, bu bağlamda hareket büyük bir siyasal güce dönüşmek ya da elitist bir çevre içinde kalma yerine toplumun bütün kesimlerine yaygınlık gösteren bir karakter sergilemiş, siyaset üzerinde belirleyici bir etki bırakmıştır (Ertürk, 2012; Des Jardins, 2006). Bu dönemde hareketlerin büyük kitlelere yayılmasının en önemli nedenlerinden 
bazıları da sağ ve sol eğilimli yaklaşımların siyasi olarak yetersiz kalmaları ve toplumun siyasi organizasyonlardan bu eğilimlere alternatif yaklaşımlar beklemeleridir(Görmez, 2010). Ayrıca özellikle nükleer karşıtı toplumsal hareketlerin birçok ülkede yaygınlık kazanması bu yaklaşımlara olan inancı arttırmıştır. Bu dönemde toplumsal hareketler kendi hareketlerinde merkeze aldıkları ekolojik kaygıların siyasi ortamda temsil edilebilmesi için çeşitli partiler kurmuşlardır. Bu partilere ekolojik kaygıları merkeze aldıkları için Yeşiller Partisi denmiştir. Almanya'da Die Grünen, Fransa'da Les Verts, İngiltere'de Green Party bu siyasi örgütlenmelerin örneklerinden sadece birkaçıdır. Bu partiler özellikle 1970'lerin ortalarından 1990'lı yıllara kadar Batı Dünyasında büyük etki bırakmışlardır. 1970'li yıllardan itibaren ortaya çıkan çevreci akımları genel karakteri itibarıyla O' Riordan tarafından üç faklı başlık doğrultusunda incelemiştir. Bu doğrultulardan ilki çevre-merkezcilik/tekno-merkezcilik doğrultusudur. Bu doğrultusu içerisinde çevre-merkezcilik doğaya doğa olduğu için sayg duyma fikrini savunur. Yararı ve insan üzerindeki olumlu etkileri için değil, kendi içerisinde özsel bir değer barındırdığı için ahlaki ilgiye konu yapma tutumunu sembolize eder. Tekno-merkezci yaklaşım ise daha çok doğayı bir kaynak olarak ele almayı savunur. Bu bağlamda, bu kaynağın en etkin bir şekilde en uzun süre ile kullanılabilmesine olanak sağlamak amacıyla gelişen teknolojiden ve uzmanlık alanlarından yararlanarak doğanın korunmasının altını çizer. Bir diğer doğrultuyu ise işlevselci/çoğulcu yaklaşımlar ile Marksist yaklaşımlar oluşturmaktadır. Bu doğrultu içerisinde çoğulcu yaklaşımlar daha çok çevre ile ilgili düzenlemelerin toplumsal düzenlemeler yoluyla gerçekleştirilebileceğini öne sürer. Toplumda bulunan adaletsizliğin ve sınıflar arası savaşın aslında çevrenin tahrip olmasında etkisinin bulunduğunu savlar. Bu yaklaşımların en önemli örneklerinden biri M. Bookchin'in Sosyal Ekolojisi'dir (Bookchin,1994). Bunun karşısında yer alan Marksist yaklaşımlar ise, toplumda oluşan mülkiyet sorunlarının ve adaletsizliğin kaynağını doğanın kaynak olarak görülmesi ve egemen erkin bu kaynağı kendi keyfince sömürmesi olarak görürler (Bookchin,1994; Bowler, 2001).

Bu bağlamda 1970'lerde ortaya çıkmış çeşitli ekolojik yaklaşımlar ele almak gerekmektedir. Bu yaklaşımları şu şekilde özetleyebiliriz;

Yeni-Malthusçuluk: Malthus'un nüfus artış hızının besin artı̧̧ hızına oranla daha hızlı arttı̆ğ tezini Sanayi Devrimi sonrasında oluşan problemlere uyarlayarak çevrenin korunması ve geliştirilmesinin altını çizen Yeni Malthusçular, gelişmemiş ülkelere yönelik olumsuz bir tutum takınmışlardır. Ancak bu ülkelerin ekolojik olarak gelişmiş ülkelerden doğaya daha az zarar verdiklerini gözden kaçırmışlardır. Yeni Malthusçuluğun en önde gelen isimleri arasında G. Hardin, P. Ehrlich ve Paddock kardeşler yer almaktadır (Mellos, 1998).

Derin Ekoloji: İnsan merkezli ekolojik tavırlara şiddetle karşı çıkan derin ekoloji, Arne Naess'in, 1973'te yayınladığı "The Shallow and the Deep: Long Range Ecology Movement: A Summary" adlı makalesinde ilk defa ele alınmış, sınırları, konusu, yaklaşım biçimleri kapsamlı bir biçimde A. Naess tarafından sistemleştirilmiştir. A. Naess derin ekolojiyi yeryüzündeki her şeyin değerli olduğu anlayışını merkeze alan ekomerkezi bir hareket olarak ele almıştır. İnsanların yaşamaları için gerekli ihtiyaçlarını, çevreyi yok etmeden sade bir biçimde doğadan alması gerektiğinin altını çizmiş bu düşünce, ekosistemdeki tüm yaşamın dengede tutulması gerektiğinin söylemektedir. Naess, yaşamın niteliğini her şeyden üstün tutmuş, insanların derin ekoloji düşüncesini benimsemesi dahilinde hayatlarında çok büyük çaplı değişikliklerin yaşanacağının altını çizmiştir (Drengson and Inoue, 1995; Önder, 2003).

Gaia Hipotezi: James Lovelock tarafindan 1970'lerde geliştirilen Gaia hipotezi derin ekoloji için temel bir dünya birliği görüşü olarak kabul edilmekte, yaklaşım olarak Doğu felsefesinde yer alan dünyanın birliği kavramının bilimsel açıklaması olarak nitelenmektedir. Hipoteze esin kaynağı olan Gaia Yunan mitolojisinde yeryüzünün Tanrısı olarak kabul edilen Gea'dan esinlenilerek oluşturulmuş bir isimdir ve Gaia prensibi yaklaşım olarak Dünya'nın kendi başına rastgele bir yapısının olmadığını, kendi içerisindeki bütün ilişkileri idare eden dev bir organizma olduğu ilkesini benimser. Yaklaşım, Dünya'daki canlı ve cansız bütün varlıkları bedenin organları gibi görür ve aralarında mistik bir etkileşimin bulunduğunu savlar (Joseph, 1990).

Mistik Ekoloji: Mistik Ekoloji kavramı daha çok Derin Ekoloji ve Gaia Hipotezinin içerisinde yer alan doğanın unsurlarının birbirleriyle olan ilişkilerinin mistisizm çerçevesinde yorumlanmasını savunur. Ayrıca mistisizm tavrı içerisinde doğayı kaynak olarak görmemek, doğayla uyumlu yaşamak, saygı göstermek fikirlerini sunar. Canlılar arasında bir hiyerarşi gütmemek ve doğa ile sezgisel ilişkiler kurarak bütünleşmeyi tavsiye eder (Bookchin,1994; Bookchin, 2017).

Ekozofi T: Derin Ekolojik yaklaşımın daha çok insanın kendini doğa aracılığı ile bütünleşme yoluyla gerçekleştirmesini merkeze alan etik tavrını ifade etmek için kullanılan Ekosofi T, Derin Ekolojinin holistik yönünü vurgulamak için ortaya atılmıştır. Yeryüzünü temel alan bir bilgelik olarak tanımlanan ekosofi, evrene ve hayata ilişkin inanç ve varsayımlarla uğraşmakta, çevre sorunlarına da bu açıdan yaklaşmaktadır. Bireylerin hayat 
tecrübelerini, sezgilerini ve ekolojik bilinçliliği içeren doğaya dayanan derin ekoloji, sadece doğayı korumaya yönelik bir hareket olmanın dışında insanın yeryüzündeki varoluşuna ve 'hayatın anlamı üzeride tutulmuş bir ışık' olarak nitelendirilmektedir. Naess'in bu yaklaşımının arkasında Doğu düşüncelerinin derin etkileri bulunmaktadır (Naess, 1973).

Ekofeminizm: Ekofeminizm, yükselen feminizm hareketleriyle birlikte, kadının erkek egemen toplumda ezilmesi ile doğanın Aydınlanma ve Modernizm anlayışı karşısında ezilmesi arasında paralelliklerin bulunduğunu savlar. Bu iki ezilme biçimi arasında anolojik ilişkiler kurulması 1970'lerde Françoise D' Eaubonne tarafindan ortaya atılmış bir ekolojik harekettir. Ekofeminizm, kadınların ezilmesi ile doğanın ezilmesi arasında doğrudan bir bağ olduğunu öngörür. Bu düşünceyi savunanlar, feminist teori ve pratiğin ekolojist bir perspektif içermesinin zorunlu olduğunu ileri sürmüş, ekolojik sorunlara getirilecek çözümlerin feminist bir perspektif içermesinin gerekliliğinin altını çizmişlerdir (Kronlid, 2003).

Sosyal Ekoloji (Toplumsal Ekoloji): Murray Bookchin tarafından geliştirilmiş bir düşünsel akım olan sosyal ekoloji, ekolojik yıkımın toplumsal ve siyasal kökenleri üzerine daha çok eğilmiş, ekolojik sorunlara tarihsel bir perspektifte ve diyalektik yöntemden yararlanarak yaklaşmıştır. Bu düşünce, olayları evrimsel bir bakış açısıyla ele alarak hem insanlığın gelişim süreci içerisinde ekolojik sorunları aramış, hem de bu sorunlara tarihte nasıl çözümlerin bulunduğunu irdelemeye çalışmış, ekolojik açıdan sorunlu bir toplumun ortaya çıkış nedenlerini ve ekolojik bir toplumun nasıl kurulabileceğini sorgulamıştır. Marksist yaklaşımın tersinden bir hareketle toplumsal eşitsizliğin ve kargaşanın ekolojik bozulmaya neden olduğunu savlamış, köklü toplumsal değişikliklerle ekolojik korunumun gerçekleşebileceğini ileri sürmüştür (Bookchin,1994; Bookchin, 2017).

Marksist Ekoloji: Marksist düşüncenin bizatihi ekolojik bir boyut içerdiği ya da mevcut ekolojik bunalıma dönük olarak Marksist düşüncenin ekolojik bir anlamda yeniden yorumlandığı Ekomarksizm, ekolojik bunalımın köklerinde toplumdaki eşitsiz mülk dağılımını yaratan Kapitalist sistemi görmektedir. Marksist terminoloji (emek/sermaye, artık ürün, üretim tesisi, toplumsal sınıflar arası eşitsizlik) ekolojik bir perspektifle yeniden yorumlanmakta; üretim-tüketim ve değer değişimi süreçlerinde fetişleşen doğa ile birlikte insanın doğaya yabancılaştı̆̆ı anlayışı temel argüman olarak ortaya çıkmaktadır. Meta üretimi ve sermayenin birikim mantığı ekolojik sorunların temelinde yatan dinamikler olarak ele alınmakta, kapitalist sistemin doğanın taşıma kapasitesini dikkate almadan sürekli arzları taşıyabilecek bir yapı olarak kurgulanması ciddi bir şekilde eleştirilmektedir (Grundmann, 1991).

Liberal Ekoloji: Serbest Piyasa çevreciliği olarak da adlandırılan liberal ekoloji, doğaya karşı insan müdahalesine karşı doğanın özgür olması gerekliliğinin altını çizer, dünyanın kendi içerisinde doğal bir sisteme sahip olduğunu, bu sistemin korunmasının ve gelecek kuşaklara bırakılmasının gerekliliğinin altını çizerler. Doğal dünya üzerinde insan türünün yarattığı zararın en aza indirilmesi ve hasarlı bölgelerin onarımını amaçlarlar. Bu bağlamda bu düşünce genel olarak bütüncül yönetim anlayışına karşı çıkar, bölgeselci bir tutumu benimser. Sürdürülebilir kalkınma stratejileri geliştirir, çevrenin insana daha büyük olanaklar sağlayabilmesi için kalitesinin yükseltilmesi gerektiğini savlar, esnekliği dinamik bir ekosistemin esası olarak ele alır (Bernstein, 2012; Bookchin,1994).

Çevre Etiği: Çevrenin tehlike içerisinde olduğu görüşünden hareketle doğa insan ilişkilerini gözden geçirerek, doğanın korunması yaklaşımını merkeze alan etik biçimine çevre etiği adı verilmiştir. Geleneksel etikten farklı olarak insan dışı varlıklarında ahlaki ilgiye değer olduğu savını merkezine alan çevre etiği, tüm doğal varlıklar ve sistemlerin kendi başlarına bir değere sahip bulunduklarını savlamış, vahşi doğa, doğada yaşayan hayvanlar, ekosistemler ve biyolojik çeşitlilik gibi konularla ilgilenmiştir (Bookchin,1994).

Hayvan Etiği (Hayvan Hakları Etiği): Hayvan hakları etiği P. Singer, T. Regan, M. Midgley gibi düşünülerce hayvanların da ahlaki ilgiye değer olduğu yaklaşımı üzerine inşa edilmiş bir yaklaşımdır. Genel olarak, hayvanların bilimsel deneylerde kobay olarak kullanılması, ticari amaçlarla ve besin olarak yararlanılması bu düşünce tarafindan sertçe eleştirilir. Bu yaklaşım, hayvanların hayvanat bahçelerinde sergi unsuru olarak ele alınmaları, evlerde zevk için kullanılmaları gibi tutum ve davranışları etik bir bakış açısı altında engelleyecek bir sistem olarak kurgulanmıştır. Düşünürleri arasında Bentham'ın teleolojik etiğini temel alan yaklaşımlar ağır basmaktadır. Bentham bilinçli varlıklar yerine hazzı ve acıyı hisseden varlıkları felsefesinin merkezine yerleştirmiş, buradan hareketle hayvan etikçileri hayvanların da haz ve acısının önemsenmesi gerekliliğini vurgulamışlardır (Kunkel, 2000).

Toprak Etiği (Yeryüzü Etiği): Toprak etiğinin kurucusu Leopord, etik sistemlerin toprağı da içerecek şekilde genişletilmesinin gerekliliğini savlamış, toprağın etik bir değer olarak ele alınabilmesi için toprağın anlaşılması gerektiğini savlamış, toprağı bir mal gibi gören anlayışlara şiddetle karşı çıkmıştır. Toprağın sağlıklı ya da sağlısız, 
yaralanmış ya da öldürülmüş canlı bir varlık olarak görülmesi gerektiğini savlamıştır. Leopold'a göre doğa korumayı ekonomik sebeplere dayandırmak ekonomik açıdan faydalı türleri ve toprakları belki korur, ancak tüm ekosistemi koruyacak yeni bir etik sistemin ortaya çıkabilmesi için gereken değişimi sağlamaz. Oysa toprağın sağlıklı işleyişi için, insana faydası olsun ya da olmasın (ticari değeri olsun ya da olmasın) ekosistemin tüm unsurlarına ihtiyaç vardır. Leopold, toprağın karmaşıklığına ve doğanın korunabilmesi için bu karmaşıklığın anlaşılmasının gerekliliğine dikkat çekmektedir (Meine, 2010; Ertan, 2015).

Chipko Hareketi: Chipko ekofeminist düşünce içerisinde kabul edilen en önemli hareketlerden biridir. 1970'li yılların başında Hindistan'ın Rani köyü içerisindeki kadınların kesilmesini istemedikleri ağaçlara sarılmak yoluyla onları korumaya çalışmalarına verilen aktivist harekettir. Bu hareket temelini Mahatma Gandhi 'nin Satragyahalarından alır. Gandhici aktivistlerin dağlık kesimlerde kadın gücünün ve çevre bilincinin gelişmesine neden olan bu hareketin başlamasındaki etkisi göz ardı edilemez. Ağaçları korumaya çalışan kadınlar, bu hareketleriyle yalnızca doğayla tinsel bir birliği ifade etmekle kalmamışlardır, aynı zamanda gündelik yaşamlarının nasıl yakacak ve yiyecek olarak ağaçlara bağlı olduğunu da kanıtlamışlardır (Downing, 2011).

Sürdürülebilirlik ve Pragmatik Ekoloji: Biyolojik sistemlerin çeşitliliğinin ve üretkenliğinin devamlılığının sağlanması amacı ile çeşitli stratejiler geliştirmeyi ifade eden sürdürülebilirlik; bugünkü doğal kaynakların en çok insana ulaşacak şekilde en etkin kullanımının sağlanması ve bu bağlamda, kaynakların mümkün olabildiğince az kullanılarak gelecek kuşaklara bırakılmasını hedefler. Bu bağlamda sürdürülebilir kalkınma kavramı; ekonomik büyüme ve refah seviyesini yükseltme çabaları ile, çevreyi ve yeryüzündeki tüm insanların yaşam kalitesini koruyarak gerçekleştirme yöntemi ile ilişkilidir. Sürdürülebilirlik insan merkezli olabileceği gibi çevre merkezli de düşünülebilen bir kavramdır. Kavram pragmatik felsefi yaklaşımın ekolojik kaygılara çözüm oluşturacak şekilde ele alınması ile oluşmuştur. Bu bağlamda Pragmatik Ekoloji, en fazla sayıda insanın en etkin bir şekilde doğadan faydalanmasını tavsiye eder. Doğal problemlere yönelik sunduğu önerilerini sürdürülebilirliğin aksine uzun vadeli teorilerin değil hızlı pratik çabaları merkeze alarak sunar (Phillips, 2003; Bookchin,1994).

Eko-Anarşizm: Bu yaklaşımın düşünürleri, doğada yardımlaşmanın bulunduğunu söyler ve toplumsal sistemlerin insanlar üzerinde baskı sistemleri kurarak insanları köleleştirdiği yaklaşımını benimseyen Anarşistlerin anlayışlarını ekolojiye uygular; onlar, ekolojik sorunların kökenini içinde yaşadığımız anti ekolojik toplumlar olarak görmüşlerdir. Eko Anarşistler, Frankfurt Okulu'nun Marksistleri T. Adorno ve H. Marcuse'ün düşünceleri ile Marshall Sahlins, Richard Lee, Lewis Mumford, J. Baudrillard ve G. Sneyder gibi düşünürlerden etkilenmiştir, insanın doğa üstüne kurduğu egemenliği sorgulamışlar, hayvanların insanların sömürüsünden kurtarılması için çeşitli kampanyalar düzenlemişler, veganlığın ve vejetaryenliğin artırılması için gayret göstermişlerdir (Morris, 2018).

Eko-Faşizm: Faşist düşüncenin ekolojik perspektif ile yeniden ele alınması ile ortaya çıkan ekofaşizm, özellikle Hitler Almanya'sındaki ekolojik yasalara dayalı olarak benimsenen ekolojik yaklaşım çerçevesinde oluşmuştur. Bu düşünce ile, Hitler zamanında doğanın ve hayvanların korunmasına yönelik yasalar çıkarılmıştır. Düşünürleri, insanın genetik olarak hayvan olması nedeniyle hayvanlarla mücadele etmenin ya da zarar vermenin, insana zarar getireceğini savlayan yaklaşımı benimsemişlerdir. Çevrecilik ile ırkçı milliyetçilik arasında bağ kuran eko-Faşistler, hayvan haklarına gösterdikleri aşırı hassas tutuma karşı insan haklarına saygı göstermemeleri nedeniyle eleştirilmişler, sağ ideolojiye yaslanan yaklaşımı ve militarist tutumları nedeniyle birçok modern ekolojist tarafindan şüpheyle yaklaşılmışlardır (Biehl \& Staudenmaier, 1995).

Eko-Sosyalizm: Sosyalist davayı/düşünceyi, ekolojik bakış açısı ve ekolojik mücadele 1şı̆̆ında gözden geçirmeyi ve yeniden yorumlamayı amaçlayan eko-sosyalizm; radikal çevreci hareketten, Marksizm ve Marksizm'in Batı'daki farklı akımlarından ve Batı sosyal demokrasisi ile bu yaklaşımların kendi aralarındaki eleştirel etkileşimden ortaya çıkmıştır. Genellikle Marksizm ilkelerine dayanan eko-Sosyalizm; kaynak gereksinmesi, kaynak kıtlığı, aşırı nüfus artışı gibi kavramları merkezine almıştır. Bu düşüncenin içerisinde yer alan köktenci sol akımlar var olan toplumsal düzenin eleştirilmesinin gerekliliğine vurgu yapar ve devletin denetimi, dar anlamdaki ulusçuluk, merkeziyetçilik gibi kavramların karşısına toplumsal ve çevresel adalet kavramını yerleştirirler. Kapitalizm'e Marksistler gibi karşı çıkmış, toplumsal krizlerin ekolojik krizleri ortaya çıkardığı savıyla da toplumsal ekolojiye yakın bir çizgiyi benimsemişlerdir (Bookchin,1994).

Ekoterörizm: Ekoteröristler yaklaşım olarak insanın doğaya zarar veren yönüne karşı onu öldürmeye kadar gidebilecek bir terörist yaklaşımı benimsemişlerdir. Akımın önde gelen isimlerinden E. Abbey, bir çıngıraklı yılanı öldürmektense bir insanı öldürmeyi tercih ederim demiş, bu ifade, bu akımın mottosu haline gelmiştir. Ağaç 
sevgilerini ağaçların gövdelerine sakladıkları kamaların testereleri kırması ile ifade eden bu grubun yaklaşımı birçok ekolojist tarafindan kabul edilmemiştir (Ronald, 2000).

Çevreci hareketlerin büyük bir bölümü, 1960'lardan sonra ekolojik hareketlerde patlama olarak gerçekleşir. Ekolojik hareketin bir sosyal hareket ortaya çıkmasının nedenlerinden temel olanı toprak, su ve havaya ilişkin ekonomik sorunlardaki dramatik artıştır. Çevreye verilen zararın bilimsel teknik açıdan ölçülebiliyor olması, küresel ısınma ve ozon tabakasının delinmesi gibi "görünmeyen" zararların dahi, ölçülebiliyor ve sonuçlarının kamuoyuyla paylaşıllyyor olması çevrenin somut bir biçimde gündemde kalmasını sağlamaktadır (Rootes, 2014). Bunun yanı sıra çevreye ilişkin zararların yerel olmaktan çıkıp evrensel boyutlara ulaşması ve insanlı̆̆ın geleceğini de tehdit ediyor olması, ekolojik hareketin oluşumuna ve gelişimine neden olmuştur. Ekolojik hareketlerin var olmasının ve yükselişinin bir diğer nedeni ise, doğadaki insan müdahalesinin hatırlatılışıdır. Ekolojik hareketlerde endüstrileşmeye yapılan vurgu, doğanın zaman içinde nasıl kökten bir şekilde değiştiğini gösterir (Ponting, 2000; Bozkurt, 2012). 70’ler itibariyle ekolojik hareketlerin ortaya çıkmasında önemli bir gelişme, o dönemde yaşanan ekonomik krizle bağlantılı olan petrol krizidir (Uslu, 1995). Bu süreçte doğal kaynakların tükenmesi petrol krizini ortaya çıkarmış, bunun yanında hava kirliliği, tarım ilaçları, çöpler, bakir doğanın kaybolması, yabani hayvan nüfusunun azalması önemlidir. Bunun yanında, zehirli maddelerin nehirlere karışması, okyanusları kirleten petrol sızıntıları, şehirdeki çocukları zehirleyen kurşunlu boyalar diğer başat sorunlardandır. Kırsal bölgeleri yutan şehirler, atık sahalarında yığılan çöp dağları ve toprağı tahrip eden sürdürülebilir olmayan tarım uygulamaları hakkındaki endişeler 70lerin dünyasında bir dizi hareketin yaşanmasına ve organizasyonun yapılmasına sebep olmuş diğer etkenlerdir (Ertürk, 2012; Krishnamurti, 2012).

\section{SONUÇ}

1960 ve 1970’ler sadece çok çeşitli ekolojik düşüncelerin dönemi olmamış, aynı zamanda birbirinden farklı uluslararası ekolojik organizasyonun, sempozyumların, kuruluşların, eylemlerin de ortaya çıktığı bir yüzyıl olma özelliğini taşımıştır. Bu dönemdeki ekolojik hareketlerin en önemli katkısı farklı konuları çevrecilik başlığı altında bir araya getirmektir. O zamana dek ayrı meseleler olarak tartışılan; doğa, insan ve yapılı çevre üçgeninde kesişen konuların birbiriyle ilintili şekilde yorumlanması gerektiğinin anlaşılması çevre hareketlerinin beklenmedik gelişime sebep olmuştur. Yayılan ve derinleşen modernitenin farklı unsurlarının neden olduğu sorun ve bunalımlar, karşısında çeşitli amaç ve aktörlerle ortaya çıkan yeni toplumsal hareketleri doğurmuştur. Bu durum, bir dizi yeni bakış açısını beraberinde getirmiş, giderek kötüleşen çevre koşulları ve doğa yıkımının gölgesinde, çevre-insan ilişkisinde çevrenin edilgen yönü yerine etken yönüne dikkat çekilmesini sağlamıştır. Özetlenebilir ki,1960'ların sonu ve 1970'lerin başındaki sivil haklar, ifade özgürlüğü ve 1970'lerdeki kadın, barış ve çevre/ekoloji hareketleri ve 1980'lerle yaygınlaşan nükleer silahsızlanma hareketleri köklü çevresel dönüşümün göstergeleridir.

Etik Standart ile Uyumluluk Çıkar Çatışması: Yazarlar herhangi bir çıkar çatışmasının olmadığını beyan eder.

Etik Kurul İzni: Bu çalışma için etik kurul iznine gerek yoktur.

Finansal Destek: Yoktur 


\section{KAYNAKÇA:}

Başkaya, F. (2004). Çı̆̆ırından çıkmış bir dünya:sosyal sefaletin, ekolojik felaketin, etik yozlaşmanın kökeni. Ankara: Türkiye ve Orta-Doğu Forumu Vakfı yayınları.

Beck, J. M. (1990). Çevre ve üçüncü dünya, çev. Kadir Canatan. İstanbul: Endülüs Yayınları.

Bernstein, S. (2012). The Compromise of Liberal Environmentalism. New York: Columbia University Press.

Biehl, J., \& Staudenmaier, P. (1995). Ecofascism: Lessons from the German experience. Edinburgh, Scotland San Francisco:CA AK Press.

Bookchin, M. (1994). Özgürlüğün ekolojisi: hiyerarşinin ortaya çıkışı ve çözülüşü. İstanbul: Ayrıntı Yayınları.

Bookchin, M. (1996a). Ekolojik bir topluma doğru. çev. Abdullah Yılmaz. İstanbul: Ayrıntı Yayınları.

Bookchin, M. (1996b). Toplumsal ekolojinin felsefesi: diyalektik doğalcıllk üzerine denemeler. İstanbul: Kabalcı Yayınevi.

Bookchin, M. (1999). Toplumu yeniden kurmak, çev. Kaya Şahin. İstanbul: Metis Yayınları.

Bookchin, M. (2017). The philosophy of social ecology: Essays on dialectical naturalism. Montréal: Black Rose Books.

Bowler, P. (2001). Doğanın öyküsü: tarih boyunca doğa hakkında düşünen filozof ve bilim adamlarının ortaya koyduğu bilgiler toplamı. çev.: Meltem Mater. İstanbul: İzdüşüm yayınları.

Bozkurt, Y. (2012). Çevre sorunları ve politikaları. Bursa: Ekin Yayınevi.

Conyne, R. K., \& Clack, R. J. (1981). Environmental assessment and design: A new tool for the applied behavioral scientist. New York, N.Y: Praeger.

Crowe, N. (1999). Nature and the idea of a man-made world: An investigation into the Evolutionary Roots of Form and Order in the built Environment. Londres: The MIT Press.

Des Jardins, J. R. (2006). Çevre etiği: çevre felsefesine giriş, çev. Ruşen Keleş. Ankara: İmge Kitabevi.

Downing, J. (2011). Encyclopedia of social movement media. Thousand Oaks, Calif: SAGE Publications.

Drengson, A. R., \& Inoue, Y. (1995). The deep ecology movement: An introductory anthology. Berkeley, Calif: North Atlantic Books.

Ertan, K. A. (2015). “Leopoldcü Düşünce ve Yeryüzü (Toprak) Etiği. Memleket Siyaset Yönetim”, 10(23), 1-20.

Ertürk, H. (2012). Çevre bilimleri. Bursa: Ekin Yayınları.

Frodeman, R., \& Foltz, B. V. (2004). Rethinking nature: Essays in environmental philosophy. Bloomington, Ind: Indiana University Press.

Gallagher, S. (2012). Phenomenology. Houndmills, Basingstoke, England; New York: Palgrave Macmillan.

Goman, M. (2014). Human environment interactions: 2. Heidelberg: Springer.

Görmez, K. (2010). Çevre sorunları. Ankara: Nobel Yayın Dağıtım. 
Grundmann, R. (1991). Marxism and ecology. Oxford: Clarendon Press.

Hamlyn, D. W. (1987). A history of Western philosophy. Harmondsworth, Middlesex, England: Viking.

Jackson, A. R. W., \& Jackson, J. M. (1996). Environmental science: The natural environment and human impact. Harlow: Longman.

Joseph, L. (1990). Gaia: The Growth of an Idea. New York, N.Y.: St. Martin's Press.

Keleş, R. \& Hamamc1, C. (1993). Çevrebilim. İstanbul: İmge Kitabevi.

Krishnamurti, J. (2012). Doğa ve çevre üzerine. İstanbul: Ayna Yayınevi.

Kronlid, D. (2003). Ecofeminism and environmental ethics: an analysis of ecofeminist ethical theory. Uppsala : [Academiae Ubsaliensis].

Kunkel, H. O. (2000). Human issues in animal agriculture. College Station, Tex: Texas A \& M University Press.

McLennan, J. F. (2004). The philosophy of sustainable design: The future of architecture. Kansas City, Mo: Ecotone.

Meine, C. (2010). Aldo Leopold: His life and work. Madison, Wis: University of Wisconsin Press.

Mellos, K. (1998). Perspectives on Ecology A Critical Essay. London: Macmillan Pres.

Morris, B. (2018). Visions of freedom: Critical writings on ecology and anarchism. Montreal: Black Rose Books.

Naess, A. (1973). “The Shallow and the Deep Long-Range Ecology Movement: A Summary". Inquiry, 16:95-100.

Önder, T. (2003). Ekoloji, toplum ve siyaset. Ankara: Odak Yayınevi.

Pepper, D. (1996). Modern environmentalism. London: Routledge.

Phillips, D. (2003). The truth of ecology: Nature, culture, and literature in America. Oxford: Oxford University Press.

Ponting, C. (2000). Dünyanın yeşil tarihi: çevre ve büyük uygarlıkların çöküşü, çev. Ayşe Başcı Sander. İstanbul: Sabancı Üniversitesi

Ronald, A. (2000). The New West of Edward Abbey. Reno: University of Nevada Press.

Rootes, C. (2014). Environmental Movements: Local, National and Global. London: Taylor and Francis.

Uslu, İ. (1995). Çevre Sorunları. İstanbul: İnsan Yayınları.

Ünder, H. (1996). Çevre felsefesi: etik ve metafizik görüşler. Ankara: Doruk Yayımcılık

West, D. (1998). Kıta Avrupası felsefesine giriş: Rousseau, Kant, Hegel ve Nietzsche'den Heidegger, Foucault ve Derrida'ya. çev. Ahmet Cevizci. İstanbul: Paradigma Yayıncılık. 